\title{
MULTI-ELEMENT ANALYSIS OF URINE USING DYNAMIC REACTION CELL INDUCTIVELY COUPLED PLASMA MASS SPECTROMETRY (ICP-DRC-MS) - A PRACTICAL APPLICATION
}

\section{RENATA BRODZKA, MAŁGORZATA TRZCINKA-OCHOCKA, and BEATA JANASIK}

\author{
Nofer Institute of Occupational Medicine, Łódź, Poland
}

Department of Toxicology and Carcinogenesis

\begin{abstract}
Objectives: The method for the determination of $\mathrm{As}, \mathrm{Al}, \mathrm{Cd}, \mathrm{Ni}, \mathrm{Pb}$ (toxic elements) and $\mathrm{Cr}, \mathrm{Co}, \mathrm{Cu}, \mathrm{Fe}, \mathrm{Mn}, \mathrm{Zn}$ (essential elements) in human urine by the use of Inductively Coupled Plasma Mass Spectrometry (quadrupole ICP-MS DRCe Elan, Perkin Elmer) with the dynamic reaction cell (DRC) was developed. Materials and Methods: The method has been applied for multi-element analysis of the urine of 16 non-exposed healthy volunteers and 27 workers employed in a copper smelter. The analysis was conducted after initial 10 -fold dilution of the urine samples with $0,1 \%$ nitric acid. Rhodium was used as an internal standard. The method validation parameters such as detection limit, sensitivity, precision were described for all elements. Accuracy of the method was checked by the regular use of certified reference materials ClinCheck ${ }^{\circledR}$-Control Urine (Recipe) as well as by participation of the laboratory in the German External Quality Assessment Scheme (G-EQUAS). Results: The detection limits $\left(\mathrm{D}_{\mathrm{L}} 3 \mathrm{~s}\right)$ of the applied method were $0.025,0.007,0.002,0.004,0.004,0.086,0.037,0.009,0.016$, 0.008, $0.064(\mu \mathrm{g} / \mathrm{l})$ for $\mathrm{Al}, \mathrm{As}, \mathrm{Cd}, \mathrm{Cr}, \mathrm{Co}, \mathrm{Cu}, \mathrm{Fe}, \mathrm{Mn}, \mathrm{Ni}, \mathrm{Pb}, \mathrm{Zn}$ in urine, respectively. For each element linearity with correlation coefficient of at least 0.999 was determined. Spectral interferences from some of the ions were removed using DRC-e with addition of alternative gas: methane for cobalt, copper, cadmium, chromium, iron, manganese, nickel and rhodium, and oxygen for arsenic. Conclusions: The developed method allows to determine simultaneously eleven elements in the urine with low detection limits, high sensitivity and good accuracy. Moreover, the method is appropriate for the assessment of both environmental and occupational exposure.
\end{abstract}

Key words:

Metals, Trace elements, Exposure, Urine, ICP-MS

\section{INTRODUCTION}

Monitoring of the concentrations of trace elements in biological material is important for clinical reasons as well as from the viewpoint of control and protection of health of individuals exposed to toxic elements. Biomonitoring permits us to assess the size of exposure and health risks of toxic factors. Biological monitoring of exposure is presently applied in environmental and occupational toxicology as well as in epidemiological studies on the dose-response relationship between internal exposure and adverse health effects of exposure to chemicals.

Usually, urine is a marker of past exposure. High concentration of an element in the urine indicates past and chronic long-term exposure to, for example: arsenic, cadmium, nickel, chromium, cobalt as well as copper or a delay in medical treatment after high occupational

Received: October 29, 2012. Accepted: February 13, 2013.

Corresponding author: R. Brodzka, Department of Toxicology and Cancerogenesis, Nofer Institute of Occupational Medicine, św. Teresy 8, 91-348 Łódź, Poland (e-mail: brodzka@imp.lodz.pl). 
exposure: lead. High concentrations of metals in blood are markers of acute current exposure. $\mathrm{Cd}$ in blood is a reliable indicator of the average industrial exposure during recent months, while whole blood $\mathrm{Pb}$ is the best indicator of exposure even though clearance from blood is significantly longer because lead is linked to red blood cells [1,2]. Some of these elements (Cr, $\mathrm{Co}, \mathrm{Mn}, \mathrm{Cu}$ ) are present in humans because they play a physiological role and they are needed for many enzymes to function. However, when at high concentrations they can be dangerous to humans. Al, As, Cd and $\mathrm{Pb}$ are classified as typical toxic elements inducing many human pathologies [3].

Systematic biomonitoring analysis allows to watch trends and to draw current conclusions regarding potential risks of the population and chemical factors which may be harmful to human health. Therefore, a simple, accurate and validated method is of primary importance.

For many years the most popular method to determine trace metals in biological materials was flame (F-AAS) or electrothermal atomic absorption spectrometry (ETAAS). Atomic absorption spectrometry equipped with graphite furnace (GF-AAS) is still successfully used in many clinical laboratories as a mono elemental method for metal determination. The major advantages of GFAAS method were selectivity and small volume of samples whereas the disadvantage - a long time of analysis. During the past decade many methods using ICP-MS to determine metals in biological matrices have been proposed [4-25]. Inductively Coupled Plasma Mass Spectrometry (ICP-MS) is the latest generation of modern, automatic systems determining elements in a wide variety of sample types. The beneficial aspects of ICP-MS are: very low limit of detection of many elements at the ppt level, high selectivity and sensitivity. These characteristic features of the apparatus allow to analyze a whole spectrum of elements in a wide range at the same time, as well as concentrations of different isotopes of the examined elements in complex matrices. Furthermore, the new technologic equipment, dynamic reaction cell (DRC), eliminates interferences that may affect sensitivity and specificity of the method.

Many authors have described methods for metals determination in urine using ICP-MS technique. Most of them as a pretreatment methods use acid nitric [3,4,26,27] or nitric acid combined with Triton X-100 [28]. Moreover, they use rodhium [26] or gal and yttrium as an internal standard [5]. In our procedure urine samples have been initially ten fold diluted with $0.1 \%$ nitric acid and were determined using quadrupole ICP-MS (Perkin Elmer Elan) with DRC technique.

The objective of this paper was to optimize and to validate the multi-element analysis of urine using quadrupole inductively coupled plasma mass spectrometry (ICP-MS) equipped with DRC. The method has been developed in accordance with the requirements of Polish/European norm PN-EN ISO/IEC 17025:2005, and it was used to assess concentrations of selected trace elements in nonexposed and exposed people.

\section{EXPERIMENTAL}

\section{Apparatus}

ICP-MS Perkin Elmer ELAN DRC-e (Sciex, USA) was used in order to optimize and validate the method of multi-element analysis of urine. ICP-MS was equipped with DRC system to eliminate spectral interference. The spectral interference may be caused by overlapping of the analyte signal and the signals from other ions (mono- or polyatomic) with the same mass/charge ratio $(\mathrm{m} / \mathrm{z})$. For instance: $4^{\circ} \mathrm{Ar}^{12} \mathrm{C} \rightarrow 5^{2} \mathrm{Cr}$ or $4^{\circ} \mathrm{Ar}{ }^{35} \mathrm{Cl}$ $\rightarrow 7^{5} \mathrm{As}$. Interference may come from both, the plasma gas components and spraying, as well as the components of the matrix of the sample [5-7]. The polyatomic interferences were eliminated using DRC with reaction gas: methane or oxygen as well as mathematical corrections. 
Methane and oxygen had purity of $99,995 \%$ for methane and of 99,999\% for oxygen (Linde Group, Poland). The use of DRC-e with ultra pure methane or oxygen as a reaction gas, was mandatory: $\mathrm{RPq}$ (as a rejection parameter q) 0.75 for $\mathrm{Cr}, \mathrm{Ni}, \mathrm{Mn}, \mathrm{Fe}$ (methane), RPq 0.8 for $\mathrm{Rh}, \mathrm{Co}, \mathrm{Cu}, \mathrm{Cd}$ (methane) and $\mathrm{RPq} 0.55$ for As (oxygen) determination.

Meinhard concentric glass nebulizer and Cyclonic spray chamber were used for sample introduction. Details of the instrumental conditions and measurement parameters of the operation are presented in Table 1.

\section{Calibration solution}

All calibration standard solutions were prepared from $10 \mathrm{mg} / \mathrm{l}$ Multi-Element Calibration Std 3 ICP-MS (Perkin Elmer Pure Plus) by proper dilution with ultra pure water (Millipore, Milli-Q Ellix 3, $\leq 18 \mathrm{M} \Omega$ ). The range of the method calibration for nine elements was from $0.1 \mu \mathrm{g} / \mathrm{l}$ to $5 \mu \mathrm{g} / \mathrm{l}$ and for $\mathrm{Al}$ and $\mathrm{Zn}$ from $1 \mu \mathrm{g} / \mathrm{l}$ to $50 \mu \mathrm{g} / \mathrm{l}$. Aqueous working standard solutions were prepared at concentrations of 1, 3, 5, 10 and $50 \mu \mathrm{g} / \mathrm{l}$ for $\mathrm{Al}$ and $\mathrm{Zn}$ and $0.1,0.5,1,3$ and $5 \mu \mathrm{g} / \mathrm{l}$ for the rest of the metals and the metalloid.

Table 1. ICP-MS operating conditions

\begin{tabular}{|c|c|}
\hline ELAN DRCe ICP-MS & Operating conditions \\
\hline RF power & $1200-1500 \mathrm{Kw}$ \\
\hline Air nebulizer gas flow & Typically $0.8-1.0 \mathrm{l} / \mathrm{min}$ (optimized daily) \\
\hline Plasma gas flow & $151 / \min$ \\
\hline Auxiliary gas flow & $1.21 / \mathrm{min}$ \\
\hline Detector mode & Dual \\
\hline Measurement units & Counts per second \\
\hline Scanning mode & Peak hopping \\
\hline Autolens & On \\
\hline Nebulizer & Meinhard \\
\hline Spray chamber & Cyclonic \\
\hline Interface & Nickel cones \\
\hline Curve type & Linear throw zero \\
\hline Sample units & $\mu \mathrm{g} / 1$ \\
\hline DRC-e with Collision gas, (RPq) & $\begin{array}{l}\text { Methane: } 0.75 \mathrm{ml} / \mathrm{min} \text { for } \mathrm{Cr}, \mathrm{Ni}, \mathrm{Mn} \text { and } \mathrm{Fe}, 0.8 \mathrm{ml} / \mathrm{min} \text { for } \mathrm{Co}, \mathrm{Cu}, \mathrm{Cd}, \mathrm{Rh} \text {, } \\
\text { Oxygen: } 0.55 \mathrm{ml} / \mathrm{min} \text { for } \mathrm{As}\end{array}$ \\
\hline Standard mode & $\mathrm{Al}, \mathrm{Zn}, \mathrm{Pb}$ \\
\hline Sweeps/reading & 20 \\
\hline Readings/replicate & 1 \\
\hline Replicates & 3 \\
\hline Dwell time & $100 \mathrm{~ms}$ (for standard and DRC mode) \\
\hline Cell gas A & $\begin{array}{l}0 \text { for } \mathrm{Al}, \mathrm{Zn}, \mathrm{Pb} \\
1 \text { for } \mathrm{Cr}, \mathrm{Ni}, \mathrm{Mn}, \mathrm{Fe}, \mathrm{Rh}, \mathrm{Co}, \mathrm{Cu}, \mathrm{Cd} \\
0,5 \text { for } \mathrm{As}\end{array}$ \\
\hline Integrator time & $\begin{array}{l}2000 \mathrm{~ms} \text { for } \mathrm{Al}, \mathrm{Zn}, \mathrm{Pb}, \mathrm{Cr}, \mathrm{Ni}, \mathrm{Mn}, \mathrm{Fe}, \mathrm{Rh}, \mathrm{Co}, \mathrm{Cu}, \mathrm{Cd} \\
3000 \mathrm{~ms} \text { for } \mathrm{As}\end{array}$ \\
\hline
\end{tabular}


For each analyzed element we obtained correlation coefficient, of at least 0.999 . In all urine samples concentrations of eleven elements were determined parallel.

\section{Internal standard}

The effectiveness of internal standardization of the inductively coupled plasma mass spectrometry was investigated for trace elements determination in urine. Parameters such as relative standard deviation, precision, and accuracy of the analytical results for gal, platinum and rodhium were compared, and rodhium was chosen as the most appropriate internal standard (IS). Rodhium stock solution, $1000 \mathrm{mg} / \mathrm{l}$ (Chem-Lab, NV, Belgium) was selected as the internal standard for all the determined metals and the mettaloid. Rhodium solution was added to calibration and to all samples in order to get the final concentration of $1 \mathrm{mg} / 1$. Afterwards, the samples were directly analyzed by the use of ICP-MS.

\section{Creatinine determination}

Urinary creatinine was measured in accordence with to Jaffe's enzymatic method using Alpha Diagnostics and spectrophotometer Eppol-20, Poll-Limited, Poland.

\section{Study groups}

The study group comprised 27 copper mill men workers who were occupationally exposed to heavy metals (mean age: 42 years within the range $26-58$ years) and 16 healthy volunteering men, occupationally not exposed (mean age: 43 years within the range $25-71$ years). The subjects were asked to complete a questionnaire, which included detailed information on the place of residence, occupational history, dietary habits, smoking and supplements.

\section{Sample collection, storage and treatment}

Spot urine samples were collected after work shift (8 h) into single use polyethylene tubes. Before samples collection all polyethylene tubes were soaked in $25 \%$ acid nitric for several hours (over $24 \mathrm{~h}$ ) and they were rinsed with ultrapure water in order to avoid contamination (especially from $\mathrm{Al}$ and $\mathrm{Zn})$. The urine samples used for trace elements determination $(5 \mathrm{ml})$ were acidified with $50 \mu \mathrm{l} 50 \%$ nitric acid (J.T. Backer) and stored in a fridge at $-20^{\circ} \mathrm{C}$. A few hours before the analysis the urine samples were brought to room temperature. Prior to determination the samples were centrifuged at 1780 RCF (4000 RPM) for $10 \mathrm{~min}$ at $4^{\circ} \mathrm{C}$ The supernatant was diluted 10 -fold with $0.1 \%$ nitric acid (high-purity $70 \% \mathrm{HNO}_{3}$, J.T. Backer) in a chamber with laminar air flow.

\section{RESULTS AND DISCUSSION}

\section{Validation parameters}

The validation parameters of the developed method are presented in Tables 2 and 3. The method was validated and optimized. Validation parameters such as: limit of detection, limit of quantification, BIAS, precision intra day, intermediate precision and recovery were evaluated. Limit of detection $\left(D_{L}\right)$ and quantification $\left(Q_{L}\right)$ was counted as 3 times $\left(\mathrm{D}_{\mathrm{L}} 3 \mathrm{~s}_{\text {for blank }}\right)$ and 6 times $\left(\mathrm{Q}_{\mathrm{L}} 6 \mathrm{~s}_{\text {for blank }}\right)$ of standard deviation for blank. The detection limits of applied method for $\mathrm{Al}, \mathrm{As}, \mathrm{Cd}, \mathrm{Cr}, \mathrm{Co}, \mathrm{Cu}, \mathrm{Fe}, \mathrm{Mn}$, $\mathrm{Ni}, \mathrm{Pb}, \mathrm{Zn}$ in the urine were very low and amounted to 0.025, 0.007, 0.002, 0.004, 0.004, 0.086, 0.037, 0.009, 0.016, $0.008,0.64(\mu \mathrm{g} / \mathrm{l})$, respectively (Table 2$)$. Very low detection limits allow us to determine all elements both in case of environmental and occupational exposure. BIAS, precision intra day and intermediate precision were calculated basing on daily used reference materials - ClinChek ${ }^{\circledR}$ and have been shown in Table 3. The precision intraday for measurements performed during one day was very good for $\mathrm{As}(0.98 \%), \mathrm{Pb}(1.03 \%), \mathrm{Al}(1.38 \%), \mathrm{Mn}$ (1.87\%), Zn (1.93\%), Fe (1.99\%), worse for $\mathrm{Cr}(2.46 \%)$, $\mathrm{Cd}(2.42 \%), \mathrm{Ni}(2.45 \%), \mathrm{Cu}(2.56 \%)$, and the worst for $\mathrm{Co}$ $(3.31 \%)$. The precision inter day for measurements was acceptable and amounted to: for $\mathrm{As}(0.78 \%), \mathrm{Pb}(1.02 \%)$, 
Table 2. The detection and quantification limits of elements in the urine

\begin{tabular}{lccc}
\hline \multicolumn{1}{c}{ Elements } & Mass / charge ratio & $\begin{array}{c}\text { The detection limits } \mathrm{D}_{\mathrm{L}} 3 \mathrm{~s} \\
(\mu \mathrm{g} / \mathrm{l})\end{array}$ & $\begin{array}{c}\text { The quantification limits } \mathrm{Q}_{\mathrm{L}} \text { 6s } \\
(\mu \mathrm{g} / \mathrm{l})\end{array}$ \\
\hline $\mathrm{Al}$ (Aluminium) & 27 & 0.025 & 0.050 \\
$\mathrm{Cr}$ (Chromium) & 52 & 0.004 & 0.008 \\
$\mathrm{Mn}$ (Manganese) & 55 & 0.009 & 0.017 \\
$\mathrm{Fe}$ (Iron) & 56 & 0.037 & 0.075 \\
$\mathrm{Co}$ (Cobalt) & 59 & 0.004 & 0.008 \\
$\mathrm{Ni}$ (Nickel) & 60 & 0.016 & 0.032 \\
$\mathrm{Cu}$ (Copper) & 65 & 0.086 & 0.173 \\
$\mathrm{Zn}$ (Zinc) & 67 & 0.064 & 0.129 \\
$\mathrm{As}$ (Arsenic) & 75 & 0.007 & 0.015 \\
$\mathrm{Cd}$ (Cadmium) & 114 & 0.002 & 0.004 \\
$\mathrm{~Pb}$ (Lead) & 208 & 0.008 & 0.016 \\
\hline
\end{tabular}

$\mathrm{Cu}$ (1.49\%), Cd (1.64\%), worse for $\mathrm{Al}(2.09 \%), \mathrm{Co}$ (2.13\%), Mn (3.07\%), Zn (3.69\%), Ni (3.71\%), and the worst for $\mathrm{Cr}(6.27 \%)$, and $\mathrm{Fe}(10.29 \%)$. The best results for these three parameters were obtained for the following eight metals: $\mathrm{Mn}, \mathrm{Pb}, \mathrm{Cd}, \mathrm{Co}, \mathrm{Al}, \mathrm{Cu}, \mathrm{Cr}, \mathrm{Ni}$ and the mettaloid As (Table 3). BIAS, precision intra day and recovery ranged from $0.005 \%$ to $10.16 \%$, from $0.98 \%$ to $3.31 \%$ and from $89.84 \%$ to $108.67 \%$, respectively.

\section{Quality control}

Now, when the methods for interpretation of the results have become the most important issue, the quality assurance system in the laboratory is necessary. Analysis of trace elements in the urine (for the purpose of systematic control, not only in the urine samples, but in general) requires the use of reference materials or certified reference materials and participation in external quality assessment (participation in the interlaboratory proficiency testing). Daily determination references or certified reference materials may be used to verify the precision of analytical methods. Using control materials is an important part of the initial assessment of the mentioned above analytical methods. Many reference materials are commercially available and many of them could be used in analyses of the urine samples.

\section{Internal quality assurance}

The method was verified by the use of reference materials: Recipe - ClinCheck ${ }^{\circledR}$-Control Urine level I and II (Munich, Germany). ClinChek ${ }^{\circledR}$ urine material based on lyophilized human urine was used for the control of occupational and environmental exposure analyses. This reference material, originally closed, was normally kept in the refrigerator at $4^{\circ} \mathrm{C}$ at least for 48 months and after reconstitution in the freezer $\left(-20^{\circ} \mathrm{C}\right)$ and at least one month and at least 7 days at the temperature $+4^{\circ} \mathrm{C}$. For the determination of $\mathrm{Zn}$ and $\mathrm{Al}$ the producer recommends using freshly dissolved sample to avoid contamination. ClinCheck ${ }^{\circledR}$ was analyzed a few times every day, always after working calibration standard solutions, blank, after every 20th real urine sample and at the end of determination series. Concentrations in the control material were in compliance with the reference values. The results of the measured concentrations and true (target) values for all the analyzed eleven elements are listed in Table 3. 
Table 3. Comparison of measured and reported concentrations in the urine reference material ClinCheck ${ }^{\circledR}$ - Control, Urine Control lyophilised, level I, II

\begin{tabular}{lrcccccc}
\hline & \multicolumn{2}{c}{ Measured } & $\begin{array}{c}\text { Reported } \\
\text { (reference })\end{array}$ & $\begin{array}{c}\text { BIAS } \\
(\%)\end{array}$ & $\begin{array}{c}\text { Precision } \\
\text { intra day } \\
(\%)\end{array}$ & $\begin{array}{c}\text { Intermediate } \\
\text { precision } \\
(\%)\end{array}$ & $\begin{array}{c}\text { Recovery } \\
(\%)\end{array}$ \\
\cline { 2 - 7 } & $\overline{\mathrm{x}}(\mu \mathrm{g} / \mathrm{l})$ & $\mathrm{n}$ & $(\mu \mathrm{g} / \mathrm{l})$ & $\frac{\mathrm{x}-\overline{\mathrm{x}}}{\mathrm{x}} \times 100$ & $\frac{\mathrm{SD}}{\overline{\mathrm{x}}} \times 100$ & $\frac{\mathrm{SD}}{\overline{\mathrm{x}} \times 100}$ & $\frac{\overline{\mathrm{x}}}{\mathrm{x}} \times 100$ \\
\hline $\mathrm{Al}$ & 157.0 & 10 & 151.2 & 3.71 & 1.38 & 2.09 & 96.29 \\
$\mathrm{Cr}$ & 35.4 & 10 & 35.5 & 0.19 & 2.46 & 6.27 & 100.19 \\
$\mathrm{Mn}$ & 21.2 & 10 & 21.2 & 0.005 & 1.87 & 3.07 & 100.00 \\
$\mathrm{Fe}$ & 213.0 & 10 & 216.9 & 1.85 & 1.99 & 10.29 & 101.85 \\
$\mathrm{Co}$ & 34.6 & 10 & 35.3 & 1.94 & 3.31 & 2.13 & 101.94 \\
$\mathrm{Ni}$ & 44.1 & 10 & 42.5 & 3.56 & 2.45 & 3.71 & 96.44 \\
$\mathrm{Cu}$ & 118.0 & 10 & 119.9 & 1.64 & 2.56 & 1.49 & 101.64 \\
$\mathrm{Zn}$ & 556.0 & 10 & 499.5 & 10.16 & 1.93 & 3.69 & 89.84 \\
$\mathrm{As}$ & 82.1 & 10 & 89.2 & 8.67 & 0.98 & 0.78 & 108.67 \\
$\mathrm{Cd}$ & 15.0 & 10 & 14.7 & 1.84 & 2.42 & 1.64 & 98.16 \\
$\mathrm{~Pb}$ & 24.0 & 10 & 24.1 & 0.39 & 1.03 & 1.02 & 100.39 \\
\hline
\end{tabular}

Abbreviations as in Table 2.

The method for the determination of trace elements in the urine was systematically checked during internal and external quality controls.

\section{External quality assurance}

The accuracy of the method for the determination of seven metals (except $\mathrm{Mn}, \mathrm{Fe}$ and $\mathrm{Pb}$ ) $\mathrm{Al}, \mathrm{Cr}, \mathrm{Co}, \mathrm{Ni}, \mathrm{Cu}$, $\mathrm{Zn}, \mathrm{Cd}$ and mettaloid As in the urine samples was verified by the participation of the laboratory in the German External Quality G-EQUAS, according to the Guidelines of the German Federal Medical Council (University of Erlangen). The coordinator assumed urine samples determination in both, occupational and environmental medical fields. Measured and target concentration for $\mathrm{Al}, \mathrm{Cr}$, $\mathrm{Co}, \mathrm{Ni}, \mathrm{Cu}, \mathrm{Zn}, \mathrm{As}$, and $\mathrm{Cd}$ are presented in Table 4. All results of the determination of eight trace elements concentrations obtained in our study were within the range of concentrations specified by the Organizer.

\section{Analysis of metals in the urine of non-exposed and exposed people}

The developed method was used in biological monitoring of metals in the urine of unexposed and occupationally exposed people. Examined population comprised 16 inhabitants of a non-contaminated area (Lódź) and 27 workers of a copper smelter. The men working in the smelter were mainly exposed to inorganic arsenic and conglomerate of other metals such as: lead $(\mathrm{Pb})$, cadmium $(\mathrm{Cd})$, nickel $(\mathrm{Ni})$, manganese $(\mathrm{Mn})$, chromium $(\mathrm{Cr})$, cobalt $(\mathrm{Co})$ as well as copper $(\mathrm{Cu})$.

Table 5 presents results of geometric mean concentrations of the elements in the urine in both subject groups - occupationally exposed and non-exposed. The results are presented in $\mu \mathrm{g} / \mathrm{l}$ or $\mu \mathrm{g} / \mathrm{g}$ creat. due to the requirements of data interpretation.

Table 6 presents well documented values of metal concentrations in the urine based on reference values and on biological tolerance values only in cases, where such data exists [29-34]. 
Table 4. Comparison of measured and target concentrations for $\mathrm{Al}, \mathrm{Cr}, \mathrm{Co}, \mathrm{Ni}, \mathrm{Cu}, \mathrm{Zn}, \mathrm{As}, \mathrm{Cd}, \mathrm{Pb}$ and creatinine of the German External Quality Assessment Scheme

\begin{tabular}{lccc}
\hline \multirow{2}{*}{ Elements } & Reference value* & Tolerance range for reference value & $\begin{array}{c}\text { Measured value } \\
\overline{\mathrm{x}} \pm \text { SD }\end{array}$ \\
\hline $\mathrm{Al}(\mu \mathrm{g} / \mathrm{l})$ & 31.00 & $22.90-39.10$ & $31.60 \pm 0.08$ \\
& 126.20 & $99.20-153.20$ & $112.50 \pm 2.80$ \\
$\mathrm{Cr}(\mu \mathrm{g} / \mathrm{l})$ & 5.00 & $3.80-6.20$ & $5.80 \pm 0.50$ \\
& 24.10 & $20.20-28.00$ & $27.20 \pm 2.20$ \\
$\mathrm{Co}(\mu \mathrm{g} / \mathrm{l})$ & 6.10 & $4.90-7.30$ & $5.20 \pm 0.05$ \\
& 31.20 & $25.50-36.90$ & $30.30 \pm 0.80$ \\
$\mathrm{Ni}(\mu \mathrm{g} / \mathrm{l})$ & 4.50 & $3.30-5.70$ & $5.40 \pm 0.60$ \\
& 31.60 & $25.60-37.60$ & $31.10 \pm 2.10$ \\
$\mathrm{Cu}(\mu \mathrm{g} / \mathrm{l})$ & 9.40 & $7.30-11.50$ & $9.10 \pm 0.80$ \\
& 49.70 & $41.30-58.10$ & $46.00 \pm 6.70$ \\
$\mathrm{Zn}(\mu \mathrm{g} / \mathrm{l})$ & 157.90 & $125.80-190.00$ & $126.20 \pm 0.60$ \\
& 330.90 & $278.40-383.40$ & $278.30 \pm 5.30$ \\
$\mathrm{As}(\mu \mathrm{g} / \mathrm{l})$ & 11.17 & $6.61-15.73$ & $10.32 \pm 1.00$ \\
& 16.87 & $10.99-22.75$ & $15.81 \pm 1.20$ \\
$\mathrm{Cd}(\mu \mathrm{g} / \mathrm{l})$ & 3.70 & $3.10-4.30$ & $3.90 \pm 0.06$ \\
$\mathrm{Creatinine}(\mathrm{g} / \mathrm{l})$ & 12.40 & $10.60-14.20$ & $12.30 \pm 0.50$ \\
& 0.74 & $0.65-0.83$ & $0.76 \pm 0.02$ \\
\hline
\end{tabular}

Abbreviations as in Table 2.

* Measured values concerned occupational and environmental range.

$\overline{\mathrm{X}} \pm \mathrm{SD}-$ mean values \pm standard deviation.

Table 5. Geometric mean urine metals concentrations $(\mathrm{xg})$ and their range for unexposed and occupationally exposed subjects

\begin{tabular}{lcc}
\hline & \multicolumn{2}{c}{ Urine metals concentrations $\left(\mu \mathrm{g} / \mathrm{g}\right.$ creat. or $\left.\mu \mathrm{g} / \mathrm{l}^{\mathrm{a}}\right)$} \\
\cline { 2 - 3 } & \multicolumn{2}{c}{$\mathrm{x}_{\mathrm{g}} \pm \mathrm{SD}_{\mathrm{g}}(\mathrm{range})$} \\
\cline { 2 - 3 } & unexposed group & exposed group \\
& $(\mathrm{N}=16)$ & $\mathrm{N}=27)$ \\
\hline $\mathrm{Al}$ & $36.23^{\mathrm{a}} \pm 2.30(9.4-141.2)$ & $44.10^{\mathrm{a}} \pm 2.00(12.3-141.7)$ \\
$\mathrm{Cr}$ & $3.03^{\mathrm{a}} \pm 1.80(1.0-11.6)$ & $4.14 \pm 1.60(1.4-11.9)$ \\
$\mathrm{Mn}$ & $0.91 \pm 2.10(0.3-3.9)$ & $1.11 \pm 1.60(0.5-3.1)$ \\
$\mathrm{Co}$ & $0.47 \pm 1.90(0.2-1.6)$ & $0.48 \pm 1.80(0.2-2.2)$ \\
$\mathrm{Ni}$ & $6.39 \pm 1.60(2.5-14.6)$ & $6.95^{\mathrm{a}} \pm 1.90(1.5-35.5)$ \\
$\mathrm{Cu}$ & $34.83 \pm 2.40(11.6-281.1)$ & $38.25 \pm 1.70(12.2-131.4)$ \\
$\mathrm{As}$ & $20.18^{\mathrm{a}} \pm 2.00^{*}(8.7-76.8)$ & $58.28 \pm 2.10(15.8-224.6)$ \\
$\mathrm{Cd}$ & $0.49 \pm 2.00(0.1-2.6)$ & $0.46 \pm 1.70(0.2-1.3)$ \\
$\mathrm{Pb}$ & $5.39 \pm 2.40^{*}(1.7-31.3)$ & $22.03 \pm 2.00(5.5-66.9)$ \\
\hline
\end{tabular}

Abbreviations as in Table 2.

$\overline{\mathrm{X}}_{\mathrm{g}}$ - geometric mean values.

$\mathrm{SD}_{\mathrm{g}}-$ geometric standard deviation.

${ }^{*} \mathrm{p}=0.05$ between unexposed and exposed group. 
Table 6. Metals concentrations in the urine determined in other studies

\begin{tabular}{|c|c|c|c|}
\hline Elements & $\begin{array}{l}\text { For non-occupationally } \\
\text { exposed people* }\end{array}$ & $\begin{array}{l}\text { For occupationally } \\
\text { exposed people** }\end{array}$ & Criteria [29-34] \\
\hline Aluminium (Al-U) & $<30 \mu \mathrm{g} / 1$ & $200 \mu \mathrm{g} / \mathrm{l}$ & $\begin{array}{l}\text { * reference value: Lauwerys, Hoet [30] } \\
* * \text { biological tolerance level - List of MAK and BAT } \\
\text { values } 2000[29]\end{array}$ \\
\hline Arsenic (As-U) & $<15 \mu \mathrm{g} / \mathrm{l}^{\mathrm{a}}$ & $35 \mu \mathrm{g} / \mathrm{g}^{\mathrm{b}}$ creat. & $\begin{array}{l}\text { * when people do not eat fish: Wilhelm et al. [31] } \\
\text { ** biological tolerance level in Poland: Augustyńska, } \\
\text { Pośniak [32] } \\
{ }^{a} \text { without fish consumption } 2 \text { days before analysis } \\
{ }^{b} \text { after work }\end{array}$ \\
\hline Cadmium (Cd-U) & $\begin{array}{l}<1 \mu \mathrm{g} / \mathrm{g} \text { creat. }^{\mathrm{a}} \\
<2 \mu \mathrm{g} \text { g creat. }\end{array}$ & $5 \mu \mathrm{g} / \mathrm{g}$ creat. & $\begin{array}{l}{ }^{* a} \text { children, men }<25 \text { years; badults }>25 \text { years }- \text { no smoking: } \\
\text { Recomendation Commission on Human Biological Monitoring } \\
\text { of the German Federal Environmental Agency [33] } \\
{ }^{* *} \text { biological tolerance level in Poland: Augustyńska, } \\
\text { Pośniak [32] - smoking causes a 2-3 fold increase of Cd } \\
\text { concentration }\end{array}$ \\
\hline Chromium (Cr-U) & $<1 \mu \mathrm{g} / \mathrm{g}$ creat. & $\begin{array}{l}10 \mu \mathrm{g} / \mathrm{g} \text { creat. }{ }^{\mathrm{a}} \\
30 \mu \mathrm{g} / \mathrm{g} \text { creat. }{ }^{\mathrm{b}}\end{array}$ & $\begin{array}{l}* \text { and }{ }^{* *} \text { biological tolerance level in Poland: Augustyńska, } \\
\text { Pośniak [32] } \\
\text { a after work minus before work }{ }^{b} \text { after work at the end of work } \\
\text { week }\end{array}$ \\
\hline Cobalt (Co-U) & $<2.0 \mu \mathrm{g} / \mathrm{g}$ creat. ${ }^{\mathrm{a}}$ & $15 \mu \mathrm{g} / \mathrm{g}$ creat. $^{\mathrm{b}}$ & $\begin{array}{l}* \text { reference value and } d^{* *}: \text { Lauwerys, Hoet }[30] \\
{ }^{a} \text { smokers may have higher levels than non-smokers }{ }^{b} \text { after work } \\
\text { at the end of work week }\end{array}$ \\
\hline Copper $(\mathrm{Cu}-\mathrm{U})$ & $<50 \mu \mathrm{g} / \mathrm{g}$ creat. & - & ${ }^{*}$ reference value and ${ }^{* *}:$ Lauwerys, Hoet [30] \\
\hline Iron $(\mathrm{Fe}-\mathrm{U})$ & $40-150 \mu \mathrm{g} / 24 \mathrm{~h}$ & - & * reference value: Pawelski, Maj [34] \\
\hline Lead $(\mathrm{Pb}-\mathrm{U})$ & $<25 \mu \mathrm{g} / \mathrm{g}$ creat. & - & * reference value: Lauwerys, Hoet [30] \\
\hline Manganese (Mn-U) & $<3.0 \mu \mathrm{g} / \mathrm{g}$ creat. & - & $*$ reference value and ${ }^{* *}$ : Lauwerys, Hoet [30] \\
\hline Nickel (Ni-U) & $<2.0 \mu \mathrm{g} / \mathrm{g}$ creat. & $\begin{array}{l}15 \mu \mathrm{g} / \mathrm{l}^{\mathrm{b}} \\
30 \mu \mathrm{g} / \mathrm{l}^{\mathrm{c}}\end{array}$ & $\begin{array}{l}\text { * reference value and } * * \text { : Lauwerys, Hoet [30] } \\
{ }^{* *} \text { biological tolerance level: DFG-EKA for Ni and its } \\
\text { compounds based on Ni } \\
{ }^{\mathrm{b}} \text { for } 100 \mu \mathrm{g} / \mathrm{m}^{3} \text { in air, after work at the end of work week } \\
{ }^{\mathrm{c}} \text { for } 300 \mu \mathrm{g} / \mathrm{m}^{3} \mathrm{in} \text { air, after work at the end of work week [29] } \\
\text { in Poland MAK } 0.25 \mathrm{mg} / \mathrm{m}^{3}\end{array}$ \\
\hline Zinc $(\mathrm{Zn}-\mathrm{U})$ & $<456 \mu \mathrm{g} / \mathrm{g}$ creat. & $<900 \mu \mathrm{g} / \mathrm{g}$ creat. & * reference value: Lauwerys, Hoet [30] \\
\hline
\end{tabular}

The study results indicated that the concentrations of trace elements in both groups are on similar level. Only for concentrations of As- $\mathrm{U}$ and $\mathrm{Pb}-\mathrm{U}$ in workers employed in the copper smelter factory the results were statistically significantly higher $(p<0.05)$ than in case of environmental exposure - the (control) group, and amounted to $58.3 \pm 2.1 \mu \mathrm{g} / \mathrm{l}$ vs. $20.2 \pm 2.0 \mu \mathrm{g} / \mathrm{g}$ creat. and to $22.0 \pm 2.0 \mu \mathrm{g} / \mathrm{g}$ creat. vs. $5.4 \pm 2.4 \mu \mathrm{g} / \mathrm{g}$ creat., respectively. In the group of occupationally exposed copper smelter workers only concentrations of arsenic $(58.3 \mu \mathrm{g} / \mathrm{g}$ creat.) exceeded Polish tolerance level (DSB) established by Interdepartmental Commision for Maximum Admissible Concentrations and Intensities for Agents Harmful to Health in the Working Environment [32] for concentration 
of total inorganic arsenic in the urine ( $35 \mu \mathrm{g} / \mathrm{g}$ creat.), about two times which is understandable because the employees worked in occupational exposure to arsenic.

There is no admissible concentrations for lead in the urine, in the workplace, because the monitoring of exposure to lead is based on the determination of lead concentration in blood samples. Chromium and cadmium had lower levels than these established by Interdepartmental Commision. Urinary aluminium concentration in our study according to the list of MAK and BAT values from Deutsche Forschungsgemeinschaft Organization in Germany [29] was also lower. Cobalt and nickel had lower levels than the data from Lauwerys et al. [30].

The geometric mean concentrations of $\mathrm{Al}, \mathrm{Cr}, \mathrm{Ni}$, As in the control (non-exposed occupationally) group $(\mathrm{N}=16)$ were significantly higher in comparison with the reference values [30-32] and exceeded the references values 1.2 times for $\mathrm{Al}, 1.4$ times for As, 3 times for $\mathrm{Cr}$ and 3.2 times for Ni (Table 5 and 6). Comparison of the content of urinary metals obtained in our control group with the world literature and the results published by Heitland et al. [3,4] and Goullé et al. [26] showed that our results were higher and concerned almost all elements. Only arsenic and cobalt concentrations obtained in our study in comparison with the results of Goullé et al. [26] were at the similar level: $20.2 \pm 2.0 \mu \mathrm{g} / \mathrm{g}$ creat. vs. $19 \mu \mathrm{g} / \mathrm{l}$ and $0.5 \pm 1.8 \mu \mathrm{g} / \mathrm{l}$ vs. $0.3 \mu \mathrm{g} / \mathrm{g}$ creat., respectively. Moreover, Asante et al. [24] revealed higher than the obtained by us level of manganese: 1.6 vs. 0.9 ( $\mu \mathrm{g} / \mathrm{g}$ creat.). Iron and zinc were not determined in the two groups concerned.

Health risk assessment is mainly based on hygiene standards. Even though the range of urinary metals concentrations for environmental and occupational exposure of people are well known, health risk assessment should include comparison of the results of the urine analysis with interpretive data. The limit values for allowable concentrations of metals in biological material in case of occupational exposure, are determined on the basis of health criteria (BAT - biological tolerance level, BEI - biological exposure indices and DSB - in Poland) or constitute an equivalent to existing maximum workplace concentration e.g. MAK (maximum workplace concentration), TLV (Threshold Limit Value), NDS (in Poland), Table 6.

\section{CONCLUSIONS}

Fast analyses of the urine and blood based on accurate methods conducted in the clinical laboratory are necessary for the rapid diagnosis and interpretation of the sources of exposure. ICP-MS technique is suitable for analysis of biological monitoring. The developed method with a set of validation parameters allows us to assess environmental and occupational exposure. The method in question, using ICP-MS technique is fast, accurate, sensitive and highly selective. Minimal sample quantity makes the method suitable for toxicological analyses. In case of toxicological analysis and particularly in case of acute exposure, rapid analyses are necessary for immediate diagnosis. Very low detection limit for all the analyzed elements allows us to perform such determinations also in children. Application of dynamic reaction cell let us avoid problems with isobaric interferences by using alternative gas: oxygen or methane. Ten fold simple dilution of the urine samples with nitric acid is sufficient to eliminate the matrix effects from the urine and enables us to use water calibration standards to calibrate the method. Nevertheless, the developed method requires the usage of the internal standards. In toxicological analysis it allows us to perform screening of elements potentially hazardous and toxic for health quickly.

\section{REFERENCES}

1. Argerer J, Weiß T. Biological Monitoring: Prospect in occupational and environmental medicine. Bonn: DFG; 2002. p. 212.

2. Jakubowski M. Biological monitoring of exposure to chemicals. Med Pr 2004;55:13-8 [in Polish].

3. Nordberg GF, Fowler BA, Nordberg M, Friberg LT. Handbook on the Toxicology of Metals. 3rd ed. USA: Elsevier; 2007. 
4. Heitland P, Köster HD. Fast, simple and reliable routine determination of 23 elements in urine by ICP-MS. J Anal At Spectrom 2004;19:1552-8. DOI: 10.1039/B410630J.

5. Heitland P, Köster HD. Biomonitoring of 30 trace elements in urine of children and adults by ICP-MS Clin Chim Acta 2006;365(1-2):310-8. DOI: 10.1016/j.cca.2005.09.013.

6. Sarmiento-González A, Marchante-Gayón JM, TejerinaLobo JM, Paz-Jiménez J, Sanz-Medel A. ICP-MS multielemental determination of metals potentially released from dental implants and articular prostheses in human biological fluids. Anal Bioanal Chem 2005;382(4):1001-9. DOI: 10.1007/ s00216-005-3165-9.

7. Krachler M, Irgolic KJ. The potential of inductively coupled plasma mass spectrometry (ICP-MS) for the simultaneous determination of trace elements in whole blood, plasma and serum. J Trace Elem Med Biol 1999;13(3):157-69.

8. Husáková L, Urbanová I, Audrlická-Vavrušová L, Šrámková J, Černohorský T, Bednaříková M, et al. Multi-element analysis of urine by inductively coupled plasma orthogonal acceleration time-of-flight mass spectrometry. Microchim Acta 2011;173:173-81. DOI: 10.1007/s00604-010-0539-2.

9. Grabeklis AR, Skalny AV, Nechiporenko SP, Lakarova EV. Indicator ability of biosubstances in monitoring the moderate occupational exposure to toxic metals. J Trace Elem Med Biol 2011;25(1):41-4. DOI: 10.1016/j.jtemb.2010.10.014.

10. Zeiner M, Ovari M, Zaray G, Steffan I. A study of the exposure of various population groups to platinum in Vienna (Austria) through urine analysis by inductively coupled plasma-mass spectrometry. Microchem J 2009;93(1):22-4. DOI: 10.1016/ j.microc.2009.04.002.

11. Szpunar J, Bettmer J, Robert M, Chassaigne H, Cammann K, Lobinski R, et al. Validation of the determination of copper and zinc in blood plasma and urine by ICP MS with cross-flow and direct injection nebulization. Talanta 1997;44(8):1389-96.

12. Wah Fong BM, Siu TS, Kit Lee JS, Tam S. Multi-elements (aluminium, copper, magnesium, manganese, selenium and zinc) determination in serum by dynamic reaction cell-inductively coupled plasma-mass spectrometry. Clin Chem Lab Med 2009;47(1):75-8. DOI: 10.1515/ CCLM.2009.006.

13. D'llio S, Violante N, Caimi S, Di Gregorio M, Petrucci F, Senofonte O. Determination of trace elements in serum by $d y$ namic reaction cell inductively coupled plasma mass spectrometry: developing of a method with a desolvating system nebulizer. Anal Chim Acta 2006;573-4:432-8. DOI: 10.1016/j. aca.2006.05.010.

14. D'llio S, Violante N, Di Gregorio M, Senofonte O, Petrucci F. Simultaneous quantification of 17 trace elements in blood by dynamic reaction cell inductively coupled plasma mass spectrometry (DRC-ICP-MS) equipped with a high-efficiency sample introduction system. Anal Chim Acta 2006;579:202-8. DOI: 10.1016/j.aca.2006.07.027.

15. D'Ilio S, Violante N, Majorani C, Petrucci F. Dynamic reaction cell ICP-MS for determination of total As, Cr, Se and V in complex matrices: still a challenge? A review. Anal Chim Acta 2011;698(1-2):6-13. DOI: 10.1016/j.aca.2011.04.052.

16. D'Ilio S, Majorani C, Petrucci F, Violante N, Senofonte O. Method validation for the quantification of $\mathrm{As}, \mathrm{Cd}, \mathrm{Hg}$ and $\mathrm{Pb}$ in blood by ICP-MS for monitoring purposes. Anal Methods 2010;2(12):2049-54. DOI: 10.1039/C0AY00429D.

17. De Blas Bravo I, Sanz Castro R, López Riquelme N, Tormo Díaz C, Apraiz Goyenaga D. Optimization of the trace element determination by ICP-MS in human blood serum. J Trace Elem Med Biol 2007;21(1):14-7. DOI: 10.1016/j. jtemb.2007.09.017.

18. Nixon DE, Moyer TP. Routine clinical determination of lead, arsenic, cadmium, and thallium in urine and whole blood by inductively coupled plasma mass spectrometry. Spectrochim Acta B 1996;51:13-25.

19. Woods G. Trace elemental analysis of undiluted urine by ICP-MS. Agil ICP-MS J Appl Chem 2011;45:4-5.

20. Sarmiento-González A, Marchante-Gayón JM, TejerinaLobo JM, Paz-Jiménez J, Sanz-Medel A. High-resolution ICP-MS determination of $\mathrm{Ti}, \mathrm{V}, \mathrm{Cr}, \mathrm{Co}, \mathrm{Ni}$, and $\mathrm{Mo}$ in human blood and urine of patients implanted with a hip or 
knee prosthesis. Anal Bioanal Chem 2008;391(7):2583-9. DOI: $10.1007 / \mathrm{s} 00216-008-2188-4$.

21. Batista BL, Rodrigues JL, Nunes JA, de Oliveira Souza VC, Barbosa F. Exploiting dynamic reaction cell inductively coupled plasma mass spectrometry (DRC-ICP-MS) for sequential determination of trace elements in blood using a diluteand-shoot procedure. Anal Chim Acta 2009;639(1-2):13-8. DOI: 10.1016/j.aca.2009.03.016.

22. Saoudi A, Zeghnoun A, Bidondo M-L, Garnier R, Cirimele V, Persoons R, et al. Urinary arsenic levels in the French adult population: The French National Nutrition and Health Study, 2006-2007. Sci Total Environ 2012;433(1):206-15. DOI: 10.1016/j.scitotenv.2012.06.053.

23. Wang J, Hansen EH, Gammelgaard B. Flow injection on-line dilution for multi-element determination in human urine with detection by inductively coupled plasma mass spectrometry. Talanta 2001;55(1):117-26.

24. Asante KA, Agusa T, Biney CA, Agyekum WA, Bello M, Otsuka M, et al. Multi-trace element levels and arsenic speciation in urine of e-waste recycling workers from Agbogbloshie, Accra in Ghana. Sci Total Environ 2012;424(1):63-73. DOI: 10.1016/j.scitotenv.2012.02.072.

25. Gil F, Hernández AF, Márquez C, Femia P, Olmedo P, López-Guarnido O, et al. Biomonitorization of cadmium, chromium, manganese, nickel and lead in whole blood, urine, axillary hair and saliva in an occupationally exposed population. Sci Total Environ 2011;409(6):1172-80. DOI: 10.1016/j. scitotenv.2010.11.033.

26. Goullé JP, Mahieu L, Castermant J, Neveu N, Bonneau L, Lainé G, et al. Metal and metalloid multi-elementary ICP-MS validation in whole blood, plasma, urine and hair. Reference values. Forensic Sci Int 2005;153:39-4. DOI: 10.1016/j. forsciint.2005.04.020.
27. De Boer JL, Ritsema R, Piso S, Van Staden H, Van Den Beld W. Practical and quality-control aspects of multi-element analysis with quadrupole ICP-MS with special attention to urine and whole blood. Anal Bioanal Chem 2004;379:872-80. DOI: 10.1007/s00216-004-2654-6.

28. Batista BL, Rodrigues JL, Tormen L, Curtius AJ, Barbosa F. Reference concentrations for trace elements in urine for the Brazilian population based on q-ICP-MS with a Simple Dilute-and-Shoot Procedure. J Braz Chem Soc 2009;20(8):1406-13.

29. List of MAK and BAT values 2000. Report No. 36; Commission for the Investigation of Heath Hazards of Chemical Compounds in the Work Area. Weinhaim (Germany): Wiley$\mathrm{VCH} ; 2000$.

30. Lauwerys R, Hoet P. Industrial Chemical Exposure Guideliners for biological monitoring. 3rd ed. Boca - London New York - Washington, D.C.: Lewis Publishers; 2001. p. 602-5.

31. Wilhelm M, Ewers U, Schulz C. Revised and new reference values for some trace elements in blood and urine for human biomonitoring in environmental medicine. Int J Hyg Environ Heath 2004;207:69-73.

32. Augustyńska D, Pośniak M. Interdepartmental Commission for Maximum Admissible Concentrations and Intensities for Agents Harmful to Health in the Working Environment. In: Jakubowski M, editor. Admissible concentrations of harmful chemicals in biological material. Warszawa: Central Institute for Labour Protection; 2003. p. 113-26.

33. Recomendation Commission on Human Biological Monitoring of the German Federal Environmental Agency. Int Arch Occup Environ Health 1999;72:255-60.

34. Pawelski S, Maj S. Standards and diagnostics of internal diseases. Warszawa: PZWL; 1993. p. 394.

This work is available in Open Access model and licensed under a Creative Commons Attribution-NonCommercial 3.0 Poland License - http://creativecommons.org/ licenses/by-nc/3.0/pl/deed.en. 